International Journal of Heritage, Tourism and Hospitality Vol. (12), No. (2/2), September, 2018 By: Faculty of Tourism and Hotels, Fayoum University, Egypt

\title{
Ahmed Urabi and his Associates: the Arrangements of the Pre-exile to Ceylon
}

\author{
Asaad A. Zaki
}

Faculty of Tourism and Hotels, University of Sadat City, Egypt

\section{Abstract}

The British force led by Garnet Wolseley defeated the Egyptian Army under the leadership of Ahmed Urabi at Tel-el-Kebir on 13 September 1882. Urabi surrendered and was imprisoned waiting for his trial. He was tried in November 1882 in front of an Egyptian court 'but it was a judicial artifice manipulated by London'. He was accused of being guilty of rebellion and refusal to disband his army at the command of the Khedive Tawfik and was sentenced to death; that sentence was commuted by the Khedive to perpetual exile from Egypt.

The focus of this work is to expose in detail the measures which were arranged by the Egyptian and the British governments when the trial of Urabi and his associates was finished and before their exile to Ceylon, beginning with the selection of the residence of exile and ending with the procedures of their transfer to Ceylon. The arrangements included what allowance should be given them for their maintenance, whether they should be allowed to select their own residence in the exile or reside in one provided by the local authorities of Ceylon, whether their correspondence would pass through the hands of the governor or not, what amount of surveillance should be exercised over them by the police of Ceylon.

This paper seeks to unearth data and stories specific to these arrangements mainly from the primary sources represented in the documents of the British Colonial Office, the correspondence of Lord Dufferin, the letters of the Governor of Ceylon and other related documents which are archived in the National Archives of the United Kingdom in London, in addition to the reports and the news which covered the trial and the exile of Urabi and his companions in different newspapers. It appears that these documents have not been previously consulted to tell the story of Urabi and his associates covering the period between the end of their trial and their arrival to Ceylon on 11 January 1882.

Keywords: Ahmed Urabi, Exile to Ceylon, Pre- exile arrangements, the British occupation of Egypt

\section{Introduction}

Ahmed Urabi and his companions were imprisoned after their defeat by the British force under the leadership of Garnet Wolseley at Tel-el-Kebir on 13 September 1882. They were tried and sentenced to death. The Khedive Tawfik (1879-1892) decided to commute the sentence to perpetual exile from Egypt. That act opened a deep discussion among the counsels of the convicted persons, the Egyptian, the British and Ceylon authorities on the proposed arrangements regarding the exile of Urabi and his associates; Ali Fahmy, Yacoup Samy, Mahmoud Samy, Mahmoud Fahmy, Toulba Esmat and Abdelaal Helmy.

This paper seeks to unearth data and stories specific to these arrangements mainly from the primary sources represented in the documents of the British Colonial Office, the correspondence of Lord Dufferin, the letters of the Governor of Ceylon and other related documents which are archived in the National Archives of the United

\footnotetext{
- Ahmed Urabi was born in 1841 in a village called Hareit Rezna east of the Nile Valley. He joined the new military academy established by Said Pasha in 1854 . He was promoted from a common soldier to a colonel in just six years in 1860 when the officer corps was opened to native Egyptians by Said Pasha (1854-1863). He participated in the 1879 rebellion which generated a general revolution against the Anglo-French dominated administration of Khedive Tawfik (1879-1892) (Rogan, 2011).
} 
Kingdom in London, in addition to the reports and the news which covered the trial and the exile of Urabi and his companions in different newspapers. The purpose of this research is to preserve and interpret facts relating to the exile of Urabi and his associates and then attempts to assimilate the facts into a meaningful order which could contribute to raising the historical awareness of the tourism guide which enables him to narrate more stories about the Egyptian history and clarify some historical facts related to the period of the British occupation of Egypt. This study depends on the historical and analytical research methods through interpretation and criticising the relevant sources and presumption of a particular event.

The British had their own interests in Egypt which led to the occupation in 1882; they wanted to keep their road and to allow shortened passage to India (Carter and Harlow, 2003). The Alexandria massacre of 11 June 1882, when more than fifty people were killed, and many shops were looted in the European quarter of Alexandria, supported the idea of the necessity of the British military existence in Egypt. That event represented a strong argument for the occupation and convinced the hesitators in England including the Prime Minister William Ewart Gladstone himself that the law and order were broken down in Egypt; Urabi Pasha, the leader of the Egyptian Army, was unable to control the situation, the lives of the Europeans were in danger and it was required to ensure the safety to the Suez Canal which was considered one of the important thoroughfares of the world trade (Chamberlain, 1977).

The British admiralty was informed on 3 June 1882 that batteries were being brought up in Alexandria with the goal of utilizing them against the British fleet. The British Foreign Secretary, Lord Granville, objected to the Porte who responded that no new strongholds were being constructed or armed, they were just few repairs and even these had been suspended on his request. The work on the batteries was begun again in the next month which led to the 9 July ultimatum of the British Admiral Sir Beauchamp Seymour which requested that unless the fortifications were surrendered to him for dismantling within twenty-four hours, he would bombard them the following morning. The Egyptian Cabinet, attended by Urabi as a Minister of War, was held on 10 July and replied that these fortifications were not considered a threat for the British vessels. The British fleet started the bombardment in the next morning 11 July which lasted for ten hours and a half and caused whole or partial destruction of the Alexandria forts, the Egyptian troops evacuated Alexandria taking up a new line of defence at Kafr el Dawar (Mansfield, 1971); it was a strong position flanked by lake of Mariut and a series of marshes. The Khedive sent an order to Urabi Pasha on 14 July to return to Ras El Tin palace in Alexandria to suspend all warlike preparations, it seems that it was just a trap; if Urabi obeyed the order, he would be arrested and if not, he would be declared out of law. Urabi rejected this order reminding the Khedive that it was his own decision to reject the British Admiral demands. As a result, the Khedive deprived Urabi of his position as Minister of War (Blunt, 1907).

A force of a few thousand British soldiers progressing from Alexandria under General Allison was resisted which contributed to the re-establishment of the Egyptian army's morale. There was the possibility of the British entry to the Suez Canal and they could turn the flank of Urabi's position, so, the Egyptians fortified a new defence line at Tel-el-Kebir. The main British force under Garnet Wolseley entered the Canal on 21 August 1882 and they surprised the Egyptian camp on 2 September and defeated the Egyptians after only thirty-five minutes fighting. Urabi retreated to Cairo where he surrendered to the British. Khedive Tawfik declared Ahmed Urabi a rebel on 1 September 1882 (Young, 1927). 
Urabi was tried in November 1882 in front of an Egyptian court 'but it was a judicial artifice manipulated by London' (Powell, 2016). Urabi was accused of being guilty of rebellion and refusal to disband his army at the command of the Khedive. He was sentenced to death; that sentence was commuted by the Khedive to permanent exile from Egypt. Such sentence meant that he would be sent off the country, and if he entered Egypt at any time again, the sentence of death would be immediately carried into execution (The daily chronicle, 1882).

The focus of this work is to expose in detail the measures which were arranged by the Egyptian and the British governments when the trial of Urabi and his associates was finished and before their exile to Ceylon, beginning with the selection of the residence of exile and ending with the procedures of their transferring to Ceylon. The arrangements included what allowance should be given them for their maintenance, whether they should be allowed to select their own residence in the exile or reside in one provided by the local authorities of Ceylon, whether their correspondence would pass through the hands of the governor or not, what amount of surveillance should be exercised over them by the police of Ceylon.

This paper seeks to unearth data and stories specific to these arrangements mainly from the primary sources represented in the documents of the British Colonial Office, the correspondence of Lord Dufferin, the British Ambassador in Constantinople, the letters of the Governor of Ceylon and other related documents which are archived in the National Archives of the United Kingdom in London, in addition to the reports and the news which covered the trial and the exile of Urabi and his companions in different newspapers. It appears that these documents have not been previously consulted to tell the story of Urabi and his associates covering the period between the end of their trial and their arrival to Ceylon on 11 January 1882.

\section{The exile residence of Urabi and his associates}

Urabi wished to live free at Damascus with his children and pledged to keep himself away from the Egyptian political affairs as long as he is out of Egypt or he could live in London 'as a free man in the land of freedom - not under custody or supervision' (Broadly, 1884). The British authorities did not respond to Urabi's desire; the British Prime Minister William Ewart Gladstone suggested that Urabi should not rest in his exile. He pointed out: 'It occurs to me that the place (of banishment) must become disagreeable perhaps even disgusting after a time to Arabi' (Galbraith, 1979).

When the trial was over, a rumour was afloat that the prisoners would be sent off to a British settlement; the Cape of Good Hope was mentioned by Lord Dufferin, the British Ambassador to the Ottoman Empire in Constantinople and was sent to Egypt following the defeat of the Urabi's revolt to recommend policies for the administration Eygpt, as a suitable place for Urabi and his companions, it was considered as Muslim colony of some fourteen thousand souls and he might find a congenial home there away from any possibility of plotting or mischief (Arabi's Exile, December 5, 1882). The British Queen refused this suggestion indicating that the Cape had its own troubles which could be increased with the arrival of Urabi and his associates (Galbraith, 1979).

Until 8 December 1882, there was no decision regarding the final residence of Urabi and his companions during their exile; Lord Dufferin sent an inquiry to the British Colonial Office regarding the destination of the prisoners sentenced to exile (The Foreign Office, 9 December 1882). The British Government decided that they should be allowed to proceed one of the British colonies at a distance from Egypt. Ceylon was selected by The British Government as the most suitable place for them, 'but not 
necessarily as his (Urabi) final place of residence' (Lord Dufferin, Telegram No. 19, 8 December 1882).

There was coordination between the British Government and the Egyptian Government regarding the procedures relative to the transfer of the prisoners from Egypt to their place of abode. Lord Dufferin wanted to know in what manner the Egyptian Government would wish the exiles to be distributed during their journey to their exile place, 'In how many batches does Egyptian gov. [Government] wish the exiled persons to be divided?' (Lord Dufferin, Telegram No. 21, 8 December 1882), and what is composition of each batch? The number of prisoners and servants, males and females for each batch (Lord Dufferin, Telegram No. 25, 12 December 1882).

The Egyptian Government wished that all the prisoners should not be exiled to the same place (Lord Dufferin, Telegram No. 24, 12 December 1882) and expressed their desire to dispose the prisoners in two batches, the destination of the first batch would be Ceylon while the second batch destination might be Hong Kong (The Colonial Office, no date), according to the proposal of Ismail Eyoup, the Egyptian Ministry of Interior, on 14 December 1882 to Alexander Meyrick Broadly, Urabi's counsel, who expressed his objection to the suggestion which was abandoned after much negotiations between Broadly and Ismail Eyoup (Broadly, 1884). The Egyptian Government approved the British proposal that all the prisoners would be exiled to Ceylon (The Colonial Office, 21 December 1882).

\section{Persons allowed to accompany the exiles}

Several negotiations were conducted between the lawyers of the prisoners, A. M. Broadly and Mark Francis Napier, in one hand and the Egyptian Government in the other hand regarding the conditions under which the exiles were to be transported to their banishment destination in coordination with the British Government (Lord Dufferin, 18 December 1882).

When the trial decision was issued, it was necessary for the prisoners to have communications with each other and with their families in the prison to arrange for their approaching departure. Ismail Eyoub, the Minister of the Interior, decided that their families were permitted to communicate with them (Broadly, 1884).

On 13 December 1882, Broadly asked the prisoners to propose a list of persons who wished to take with them to Ceylon. A list of 130 persons was prepared on the following day; Ismail Eyoup objected to the list and pointed that the prisoners had to shorten it (Broadly, 1884). The same list was sent to Lord Dufferin, it included not only the prisoners but also a number of their relatives and servants which was unreasonable from Lord Dufferin's point of view as the Egyptian Government would pay about five thousand pounds for hiring a ship in addition to incidental expenses amounting to three thousand pounds. Moreover, the chartered ship had only twenty first class places for passengers and thirty second class places which means that they would need another ship to transport the prisoners and their companions; Lord Dufferin said that it was unthinkable to hire another ship and he informed the Egyptian Government that the prisoners were only allowed to take their immediate relatives with them such as wives, sisters or children, one servant for each of the men, one maid for their wives and a nurse for their children if it was sufficient. At the same time, the prisoners could be provided with any additional servants or to be joined by any other relatives who could travel to Ceylon in an ordinary passenger ship. The list was shortened to have only the names of fifty-two persons including the seven exiles themselves (Lord Dufferin, 18 December 1882). 


\section{The Governor of Ceylon's authority over the exiles}

The Governor of Ceylon was officially informed that Urabi and his associates would reside in Ceylon on parole on 24 December 1882. This decision meant that they would not leave Ceylon without previous obtained permit from the British Government. It is worth mentioning that Urabi and his companions were not considered as in the custody of Ceylon Government, it would be no part of the Governor of Ceylon duty to prevent forcibly their departure from the Island (The Colonial Office, 19 December 1882), but he would immediately inform the British Foreign Office of their departure from the Island which means that they broke their parole (The Under Secretary of State of Foreign Office, 24 December 1882), the Governor of Ceylon accepted this instruction stating that he would keep Lord Granville and the Viceroy of India informed of any movements on the part of the exiles which might indicate that they might leave Ceylon (Longden, 21 January 1883).

There was a discussion within the British authority's offices regarding the extent of the supervision which would be exercised over the prisoners' correspondence after their arrival at Ceylon. Lord Granville suggested that arrangements should be made by the Government of Ceylon for exercising a supervision over their correspondence which means that their correspondence would pass through the hands of Ceylon authorities (The Foreign Office, 21 December 1882).

The Governor of Ceylon was not encouraged by such a measure and suggested to exercise a supervision over the correspondence of the exiles at Suez in Egypt where the mails of Egypt were landed. The Governor had his own reasons for calling this opinion; as some of the exiles left a number of their family members behind in Egypt, they would maintain confidential communications with them in Arabic and could not be supervised in Ceylon without the assistance of Arabic interpreters which might excite public suspicions, moreover, there were not Arabic interpreters to be had in Ceylon whom he could trust, even if the law permitted them to open the private correspondence which it did not. The Governor stated that the situation in Egypt was greatly different as the exiles were considered rebels by their Government and the supervision over their correspondence could be explained as 'an act of self-protection' which the State may exercise in such circumstances, he suggested that the mails could be opened and supervised by the Khedive's officers without exciting the Egyptian public feelings (Longden, 21 January 1883).

\section{The surveillance over the exiles in Ceylon}

Regarding the amount of surveillance which should be exercised over the exiles by the police of Ceylon, it was up to the local authorities in Ceylon to use their discretion as the British Colonial Office stated that the colonial authorities 'would have no greater legal power over the exiles than over any other resident' (The Colonial Office, no date).

The British Foreign Office instructed the Governor of Ceylon to select a careful officer to exercise 'inoffensive close surveillance' over the movements of Urabi and the other principal exiles, and they should be informed of any communications which might be made to the exiles by the Muslims or other sympathisers whether resident in Ceylon or visiting it after their arrival. Because of Ceylon's proximity to India, the Governor of Ceylon was instructed to inform the Government of India of any relations of the prisoners with persons in India or that any of them contemplate visiting it (The Under Secretary of State Foreign Office, 24 December 1882). 
The presence of those nationalists in Ceylon posed a danger to the British authorities not only in Ceylon but also in India because in the event of any Muslims enthusiasm, Urabi and his companions, who were considered heroes, might join it; Urabi's name could provide a leader for any movement. Urabi and the other nationalists were not totally isolated in Ceylon by race or religion. The Muslims community in Ceylon was about two hundred thousand, 184.536 of them were moors who were fanatical Muslims from the Ceylon authorities' point of view and descended from an Arabic nationality. Morice Bey, the English officer who travelled to Ceylon accompanying the exiles, told the Governor of Ceylon that they spoke an Arabic which was very similar to the Arabic spoken in Egypt which would ensure daily conversation with their co-religionists. Many of the moors of Ceylon were engaged in trade and had commercial relations with different parts of India which could open a door to Urabi and his associates to arouse curiosity and sedition among the Indians (Longden, 21 January 1883). The police in Ceylon should watch out for them and their influence on the Muslims (Wenzlhuemer, 2008).

The Governor of Ceylon appointed Lieutenant Hausard of the Ceylon Office to keep him informed of the movements of Urabi and his associates; Lieutenant Hausard was carefully selected for this duty, he was formerly in the army and served the Ceylon Government for fifteen years, ten of which had been in the police. During that time, he held the position of Superintendent of Police in the Western Province including Colombo which was considered the most important office under the Inspector General, and his official position would enable him to exercise an adequate surveillance over the exiles (Longden, 21 January 1883).

\section{The residence selection in Ceylon}

Regarding the point that whether Urabi and his companions should be allowed to select their own residence in Ceylon, or reside in one provided by the local authorities, the Governor of Ceylon was responsible of providing a place of residence for the exiles only in the first days of their arrival, the prisoners would eventually be permitted to select their own residence on the island (The Colonial Office, 21 December 1882).

The Governor of Ceylon suggested that this choice should be object to a little restriction; it was unadvised to reside the exiles in two certain districts for different reasons, one in Jaffna and the other was Batticaloa. Jaffna is nowadays the capital city of the Northern Province of Sri Lanka, it is about 33 miles from the Indian coast and there was daily communication by native vessels between the ports of the Jaffna district (Kayts, kankesanturai and Point Pedro) and the small Indian ports which would require very close surveillance over the exiles who would live at Jaffna to prevent them from shipping secretly to India. Batticaloa was the former capital of the Eastern Province of Sri Lanka, it is on the eastern coast, very far from Colombo to allow easy supervision (about $318 \mathrm{~km}$ away from Colombo), there was a large coasting trade between Batticaloa and Jaffna, moreover, Batticaloa had a large Muslim community during that time, 43.583 Muslims in a total population of 127.555 (Longden, 21 January 1883).

The British Government expected the Egyptian Government to propose a maintenance allowance for the exiles (Lord Dufferin, Telegram No. 25, 12 December 1882). The property of the exiles was confiscated by the Egyptian Government who proposed to make them an allowance for maintenance of themselves and their dependants of $£ 30.15$ a month each out of their confiscated properties (The Colonial Office, 21 December 1882). The exiles received two months pay in advance before leaving 
Egypt which would enable them to provide for their immediate needs (Douglas, January 1883).

\section{The transportation of the exiles to Ceylon}

The Egyptian Government was required to provide a ship for the prisoners' transportation and accommodation on the board ship as well. the Egyptian Government hired a large English ship 'Mareotis' of thirteen hundred and ninety-two tons for the purpose, the steamer was modified to fit as many passengers as possible because the exiles wanted to travel altogether on the same ship to Ceylon (Broadly, 1884). They were provided with a stewardess on board. Captain Morice Bey, the English naval officer in the Egyptian service, accompanied the party to their destination. Broadly praised the Egyptian Government for these arrangements which were carried out regardless of expenses (Lord Dufferin, 18 December 1882). The political exiles wrote a declaration before their departure from Suez expressing their satisfaction and gratitude for the arrangements they found on the board ship 'Mareotis' (Lord Dufferin, Telegram No. 72, 31 December 1882).

The Egyptian Government sent an intimation to Urabi and his companions to be ready about ten days before their departure (The Exile of Arabi, December 14, 1882). The steamer left Egypt with the exiles on 26 December 1882. The Governor of Ceylon had the right to arrange with the Captain of the vessel to proceed to any port in Ceylon; Colombo port was selected. As the ship was hired by the Egyptian Government and the responsible officer on board who represented them was Morice Bey, it was necessary for Lord Dufferin to ask the Egyptian Government to direct Morice Bey to order the Captain to land the prisoners at whatever port the authorities of Ceylon may indicate (Lord Dufferin, 31 December 1882).

\section{The exiles arrival to Ceylon}

The exiles' steamer arrived in Colombo Harbour at 5 o'clock afternoon of 10 January 1883. John Douglas, the lieutenant governor of Ceylon was on board to inform the exiles of the arrangements which had been made for their reception and to arrange for their landing. The exiles and their families, fifty-two persons, landed on the following day 11 January 1883 (Longden, 13 January 1883). Morice Bey assured the Governor of Ceylon that Urabi expressed his satisfaction which he felt at his reception arrangements (Longden, 20 January 1883).

The British Government received an offer from the New Oriental Hotel Co. to place their hotel at Point de Galle (Galle is located on the southwestern coast of Sri Lanka, 72 miles away from Colombo) as a temporary residence for the political prisoners upon their arrival (The Foreign Office, 15 December 1882). The offer could not be accepted because the Government of Ceylon had rented four houses for the exiles before receiving it (Longden, 20 January 1883). The four houses were located in or near the common gardens in Colombo and were rented at an aggregate monthly rental of 500 rupees. Each house had a caretaker, a cook and a female attendant placed by the Ceylon authorities. Ali Fahmy's family who was numbered fourteen had a house, Yacoup Samy's family with its twelve members had another house, Mahmoud Samy's family which had only three members and Mahmoud Fahmy's family who was numbered nine resided in a large house in which their families could kept separately, while the Family of Ahmed Urabi with his five dependents, the family of Toulba Esmat with his two family members, and Abdelaal Helmy who was accompanied by four persons, stayed at the same house because they had few family 
members, that house had many bed and reception rooms (The Colonial Office, 21 February 1883).

A large crowd received Urabi and his companions at Colombo Harbour; most of them were Muslims and few Europeans. The Muslim population of Ceylon warmly sympathized with the exiles because they had a common religion. The Muslims of Ceylon were numbered 197.775, of whom 32.208 lived in the city and suburbs of Colombo during that time. The Governor of Ceylon stated that those Muslims were the most energetic race in the Island. When Urabi landed, there was much excitement and he was followed by a large crowd of his co-religionists and round his carriage to kiss his hand, Urabi enthusiastically raised his hand thanking them. The only request which was made by the exiles that their children could attend a good school in Colombo (Douglas, January 1883).

\section{Conclusion}

Urabi and his associates could not be accompanied with all persons they want to Ceylon; they expressed their desire to take 130 persons with them including a number of their relatives and servants, this list was shortened according to the instructions of Ismail Eyoup and Lord Dufferin; there was no objection for the prisoners to be accompanied by any number of persons in Ceylon, but the ship which was hired to transport the exiles and their families to Ceylon could not accommodate this number of passenger and it was unreasonable to hire another steamer from the Egyptian and the British governments point of view which would cost additional expenses. The list of accompanying persons was shortened to have only fifty-two persons including the seven exiled persons themselves.

The exile place of Urabi and his associates was selected by the British Government in coordination with the Egyptian Government; the British decided that Urabi and his companions would be exiled to one of the British colonies at a distance from Egypt and Ceylon was selected. Although Urabi and his associates would reside in Ceylon on parole, they were not considered in the custody of Ceylon Government. The Governor of Ceylon was not authorized to prevent forcibly their departure from the Island, but he should immediately inform the British Foreign Office in case of their departure.

The right of the private correspondence secrecy of the exiles was not limited in Ceylon; the measure of exercising a supervision over the exiles' correspondence in Ceylon was not accepted by the Governor of Ceylon as he could not find Arabic interpreters whom he could trust, and the law did not permit him to open the private correspondence. It was not a moral aspect of the case as he suggested violating the confidentiality of the correspondence by the Egyptian authorities in Egypt.

The British authorities decided that a close surveillance should be exercised over the movements of Urabi and the other principal exiles in Ceylon, and the British Foreign Office should be informed of any communications which might be made to the exiles by the Muslims or other sympathisers in Ceylon.

The British Government determined that the exiles would be allowed to select their place of residence everywhere in Ceylon except two certain districts, Jaffna and Batticaloa. The exiles accommodation in Jaffna, located close to the Indian coast, 33 miles, would require very close surveillance over the exiles to prevent them from shipping secretly to India. While Batticaloa, on the eastern coast, is very far from Colombo to allow easy supervision. Colombo was finally selected as a place of their residence in Ceylon. 
Although there was coordination between the Egyptian and the British governments regarding the pre-exile arrangements, the British had the upper hand in taking some measures on some issues such as the selection of the exile place and the post-exile arrangements which would be conducted in Ceylon like the decision of giving the exiles the right to select their own residence in Ceylon with some restrictions and the amount of surveillance which should be exercised over them, while the Egyptian Government paid the costs of their transportation from Egypt to Ceylon and pledged to pay an allowance for the exiles maintenance throughout their exile in Ceylon.

The paper recommends future studies to be carried out on the exiled persons in Ceylon after their arrival; whether the allowance was enough for the exiles and their dependents or not, their correspondence was supervised or not in Ceylon, what amount of surveillance which was actually exercised over them, how were their relationships with the Muslims or other sympathisers in Ceylon, what were the exiles attempts to return back home, and how did the Egyptian and the British governments deal with the exiles' requests? The research recommends other future studies to be carried out on the other Egyptians who were exiled during the British occupation of Egypt such as Ahmed Shawky and Saad Zaghlul and trying to compare the measures of Urabi's exile with those of the other Egyptian exiles.

\section{References}

"Arabi's Exile." (1882), The Manchester Guardian, December 5.

"The Daily Chronicle." (1882), The Huddersfield Daily Chronicle.

"The Exile of Arabi," (1882), The Morning Post (London, England), December 14.

Blunt, Wilfrid Scawen (1907), Secret History of the English occupation of Egypt: Being a Personal Narrative of Events, Chiswick Press, London.

Broadly, Alexander Meyrick (1884), How We Defended Arabi and his Friends: A Story of Egypt and the Egyptians, Chapman and Hall, London.

Carter, Mia and Barbara Harlow (2003), Archives of Empire: volume 1 from the east India to the Suez Canal, Duke University Press, Durham.

Chamberlain, M. E. (1977), "The Alexandria Massacre of 11 June 1882 and the British Occupation of Egypt," Middle Eastern Studies 13, no.1.

Douglas, John, Lieutenant Governor of Ceylon (January 1883), Report about the arrival of the Egyptian exiles in Colombo, FO 78/4267, Egyptian Exiles in Ceylon: Arabi \& C. 1882-83, the National Archives of the United Kingdom, Surrey, UK.

Galbraith, John S. (1979), "The trial of Arabi Pasha." The Journal of Imperial and Commonwealth History 7, no. 3.

Longden, J. the Governor of Ceylon (13 January 1883), Letter to Lord Granville, FO 78/4267, Egyptian Exiles in Ceylon: Arabi \& C. 1882-83, the National Archives of the United Kingdom, Surrey, UK.

(20 January 1883) Letter to Lord Granville, FO 78/4267, Egyptian Exiles in Ceylon: Arabi \& C. 1882-83, the National Archives of the United Kingdom, Surrey, UK.

(21 January 1883) Letter to Lord Granville, FO 78/4267, Egyptian Exiles in Ceylon: Arabi \& C. 1882-83, the National Archives of the United Kingdom, Surrey, UK.

Lord Dufferin, (Telegram No. 19, 8 December 1882), FO 78/4267, Egyptian Exiles in Ceylon: Arabi \& C. 1882-83, the National Archives of the United Kingdom, Surrey, UK.

(Telegram No. 21, 8 December 1882), FO 78/4267, Egyptian Exiles in Ceylon: Arabi \& C. 1882-83, the National Archives of the United Kingdom, Surrey, UK. 
(Telegram No. 25, 12 December 1882), FO 78/4267, Egyptian Exiles in Ceylon: Arabi \& C. 1882-83, the National Archives of the United Kingdom, Surrey, UK.

(18 December 1882), Letter to the Foreign Office, FO 78/4267, Egyptian Exiles in Ceylon: Arabi \& C. 1882-83, the National Archives of the United Kingdom, Surrey, UK.

(31 December 1882), Letter to Earl Granville, FO 78/4267, Egyptian Exiles in Ceylon: Arabi \& C. 1882-83, the National Archives of the United Kingdom, Surrey, UK.

(Telegram No. 72, 31 December 1882), to Lord Granville, FO 78/4267, Egyptian Exiles in Ceylon: Arabi \& C. 1882-83, the National Archives of the United Kingdom, Surrey, UK.

Mansfield, Peter (1971), the British in Egypt, Weidenfeld and Nicolson, London.

Powell, Michael (2016), "The Clanking of Medieval Chains: Extra-Judicial Banishment in the British Empire," The Journal of Imperial and Commonwealth History 44, no. 2.

Rogan, Eugene (2011), The Arabs: A History, Basic Books, New York.

The Colonial Office (19 December 1882), Letter to the Governor of Ceylon, FO 78/4267, Egyptian Exiles in Ceylon: Arabi \& C. 1882-83, the National Archives of the United Kingdom, Surrey, UK.

The Colonial Office (21 December 1882), FO 78/4267, Egyptian Exiles in Ceylon: Arabi \& C. 1882-83, the National Archives of the United Kingdom, Surrey, UK

The Colonial Office (21 February 1883), FO 78/4267, Egyptian Exiles in Ceylon: Arabi \& C. 1882-83, the National Archives of the United Kingdom, Surrey, UK.

The Colonial Office (no date), FO 78/4267, Egyptian Exiles in Ceylon: Arabi \& C. 1882-83, the National Archives of the United Kingdom, Surrey, UK

The Foreign Office (9 December 1882), Letter to the Colonial Office, FO 78/4267, Egyptian Exiles in Ceylon: Arabi \& C. 1882-83, the National Archives of the United Kingdom, Surrey, UK.

The Foreign Office (15 December 1882), Letter to the Colonial Office, FO 78/4267, Egyptian Exiles in Ceylon: Arabi \& C. 1882-83, the National Archives of the United Kingdom, Surrey, UK.

The Foreign Office (21 December 1882), Letter to the Colonial Office, FO 78/4267, Egyptian Exiles in Ceylon: Arabi \& C. 1882-83, the National Archives of the United Kingdom, Surrey, UK.

The Under Secretary of State Foreign Office (24 December 1882), Letter to the Governor of Ceylon, FO 78/4267, Egyptian Exiles in Ceylon: Arabi \& C. 188283, the National Archives of the United Kingdom, Surrey, UK

Wenzlhuemer, Roland (2008), From Coffee to Tea Cultivation in Ceylon 1880-1900: An Economic and Social History, Brill, Leiden.

Young, George (1927), the Modern World a Survey of Historical Forces: Egypt, Charles Scribner's Sons, New York. 